\title{
DIE ONTSTAAN EN ONTWIKKELING VAN DIE STAFAFDELING HOOF VAN STAF PERSONEEL
}

\author{
Kapt R. Von Moltke*
}

The origin of the Staff Section Chief of Staff Personnel can be traced back to the year 1912, when the Union Defence Force came into being. Changes occured in the command and control structure of the Union Defence Force (from 1957 the SADF), changes very often also affecting the Staff Section Chief of Staff Personnel. The history of Chief of Staff Personnel is depicted in this article from 1912 to the present date.

\section{Inleidend}

Die geskiedenis van die Afdeling Personeel as Stafafdeling van die Suid-Afrikaanse Weermag is onlosmaaklik verbonde aan die ontwikkeling en uitbreiding van die bevel- en beheerstruktuur van die SAW. Die ontstaan van die Atdeling Personeel kan teruggevors word tot in 1912 toe die Unieverdedigingsmag tot stand gekom het. Van tyd tot tyd het veranderinge plaasgevind in die bevel- en beheerstruktuur van die Unieverdedigingsmag en sedert 1957 van die SAW. Hierdie veranderings het by meer as een geleentheid ook die Afdeling Personeel geraak. Ter wille van die logiese benadering van die onderwerp word die geskiedenis van die Afdeling Personeel vervolgens benader aan die hand van die benaminge van die posbekleërs van die afdeling soos dit sedert 1912 voorgekom het.

\section{Die tydperk van die Adjudant-generaal}

Met die totstandkoming van die Unieverdedigingsmag in 1912 het die personeelfunksie ten opsigte van militêre personeel geresorteer onder die Afdeling van die Generale Staf. Maj (tydelik) J.J. Collyer het sedert 1 Julie 1912 die pos Stafoffisier, Generale Stafpligte beklee en in hierdie hoedanigheid ex officio opgetree as hoof van die Afdeling Personeel. Daar is op daardie stadium nie spesifiek na die Hoof van Personeel verwys nie, aangesien maj Collyer se beheerfunksie oorkoepelend van aard was.

Gedurende 1915 is die pos Stafoffisier, Generale Staf hernoem na Hoofstafoffisier, Generale Staf en Adjudant-generaal (AG). Hierdeur is die personeelfunksie erken as afsonderlike staffunksie, maar dit was egter nog 'n 'tweehoed' -aanstelling en die posbekleër vir beide die poste

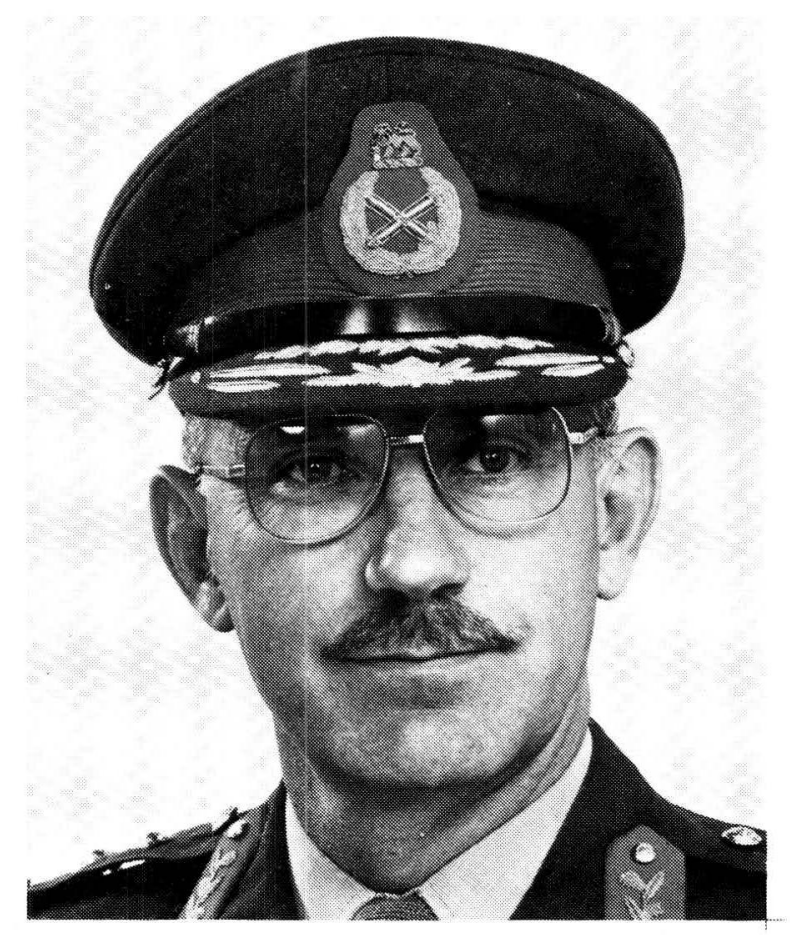

Lt-genl R.F. Holtzhausen, SM Hoof van Staf Personeel sedert 1 Januarie 1981

was dieselfde persoon. Op 4 Junie 1917 het die Hoofstafoffisier, Generale Staf en Adjudantgeneraal die Hoof van Generale Staf (HGS) en Adjudant-generaal geword.

Die pos van AG is op 5 Junie 1918 van die HGS geskei, hoewel die posbekleër nog vir meer as 'n jaar dieselfde persoon sou bly. Eers op 14 Oktober 1919 het Collyer opgehou om as AG te fungeer. Op 1 November 1919 is ' $n$ afsonderlike posbekleër as AG aangestel toe It-kol W.E.C. Tanner AG geword het. In wese het dit daarop neergekom dat die $A G$ afgestig het van die HGS. Daardeur het die Afdeling Personeel 'n volwaardige, selfstandige afdeling geword. 
Hierdie posisie het sedertdien onveranderd gebly en die Afdeling Personeel sou steeds al hoe meer verantwoordelikhede onder sy sambreel bykry. Tesame met die afdeling van die Kwartiermeester-generaal (KMG) en die afdeling vir Geneeskundige Dienste (SOGD) was die AG afdeling een van die drie stafafdelings wat naas die afdeling van die Generale Staf direk onder die Minister van Verdediging geresorteer het.

Die tydperk onmiddellik na die Eerste Wêreldoorlog is gekenmerk deur grootskaalse besnoeiing van staatsuitgawes. Daar kon gevolglik ook nie veel ontwikkeling of uitbreiding geskied aan die kant van die Unieverdedigingsmag (UVM) nie. Namate die ekonomie sterker geword het, kon kleinskaalse uitbreiding toegelaat word. Belangrike langtermyn uitbreiding van die UVM is teen die einde van die dertigerjare beplan en die nodige fondse is daarvoor bewillig, maar die uitbreek van die Tweede Wêreldoorlog het hierdie program verongeluk. Organisatories was daar feitlik geen verandering sover dit die Afdeling Personeel betref nie. In 1939 is die pos van die AG, wat toe bekend gestaan het as die AG en DGR (Direkteur-generaal Reserwes) opgegradeer na Direkteur-generaal. In 1940 is die DGR as afsonderlike pos afgeskaf en is die pos opgeneem in die afdeling van die AG.

Die uitbreek van die Tweede Wêreldoorlog het belangrike implikasies gehad vir die UVM. Die geweldige toename in personeel as gevolg van die oorlog het ook uitbreiding van die Afdeling Personeel genoodsaak. Van belang in hierdie opsig was veral die geweldige taak wat na die oorlog gepaard gegaan het met demobilisasie. Nuwe afdelings moes spesiaal vir dié doel geskep word. Gedurende 1942 is die pos van AG opgegradeer na generaal-majoor. ${ }^{1}$ Dit kan gesien word as 'n erkenning van die toenemende belangrikheid van die Afdeling Personeel.

In teenstelling met die grootskaalse besnoeiing na afloop van die Eerste Wêreldoorlog, is dieselfde beleid gelukkig nie na afloop van die Tweede Wêreldoorlog gevolg nie. 'n Tydperk van ontwikkeling en heropbou het gevolg wat ongekend was in vredestyd in Suid-Afrika. Die na-oorlogse herorganisasie het onder andere ingesluit die instelling van Stafhoofde vir die drie weermagsdele, naamlik die Leërstafhoof, die Lugstafhoof en die Vlootstafhoof. 'n Inspekteurgeneraal is ook aangestel. Die drie Stafhoofde, tesame met die AG, KMG en Geneesheer-generaal (GG) het die HGS bygestaan in sy pligte.
Die afdeling van die AG was teen 1946 georganiseer in 'n reeks ongekoördineerde afdelings wat deur die Adjunk AG (Adj AG) en die AG beheer is. Die verantwoordelikhede van die Adj AG was so uitgebreid dat dit nouliks hanteerbaar was. Gevolglik is daar besluit om sekere personeel-onderafdelings (AG1: Offiisiere, AG4: Ander Range, AG2: RAG (Regteradvokaatgeneraal), AG5: Onderskeidings en Toekennings, HBM sowel as die Kapelaansdienste) direk onder beheer van die AG te plaas. Dit het meegebring dat die $A G$ in so 'n mate belas is met administratiewe pligte dat hy nie meer aandag kon gee aan ander belangrike pligte nie. Dit het gelei tot 'n nuwe bedeling waarin nuwe poste geskep moes word, omdat uitbreiding van die Afdeling Personeel onvermydelik geword het. Interne personeelskommelings het van tyd tot tyd plaasgevind, maar in wese het die organisasie van die AG se afdeling dieselfde gebly. Die eerste belangrike veranderinge sou eers teen die einde van die vyftigerjare begin plaasvind.

Die aanname van die Verdedigingswet, no 44 van 1957, het 'n nuwe era in die Suid-Afrikaanse militêre geskiedenis ingelei. Belangrike veranderinge ten opsigte van die naam van die HGS en die UVM het ook in hierdie tydperk plaasgevind. Reeds in 1956 is die ampstitel van die HGS verander na dié van Kommandant-generaal (KG). In 1957 het die naam UVM plekgemaak vir die Suid-Afrikaanse Weermag (SAW). Daar is ook begin om die stafafdelings op weermagsgrondslag te organiseer. Elke weermagsdeel was sedert 1957 betrokke by personeelaangeleenthede van sy weermagsdeel.

Op 31 Desember 1960 is die pos van Inspekteur-generaal afgeskaf en het dit die Direktoraat Beplanning en Operasies van die Staf van die KG, SAW geword. Die Militêre Inspektoraat se personeel is oorgeplaas na die afdeling van die. AG met ingang van 1 Januarie 1961.

\section{Die Adjudant-generaal word Hoof van Weermagsadministrasie}

Gedurende die sestigerjare moes daar kort-kort organisatoriese veranderinge ten opsigte van die bevel- en beheerstruktuur van die SAW plaasvind om tred te hou met die snelle ontwikkeling en uitbouing van die SAW. Die eerste belangrike opknapping van die bevel- en beheerstruktuur is in 1966 uitgevoer. Vier nuwe bevel- en beheerliggame is ingestel, te wete die 
Opperbevel (bestaande uit die KG as voorsitter, die onderskeie afdelingshoofde en belangrike senior amptenare op uitnodiging van die KG wat as adviseurs vir die $K G$ moes optree), die Verdedigingstaf, die Hoofkwartier Gesamentlike Gevegsmagte en die Hoofkwartier Maritieme Verdediging.

Daarbenewens is ' $n$ herindeling van die funksies van die $A G$ en KMG gemaak en die ampstitels van die hoofde van die betrokke afdelings is verander na Hoof van Weermagsadministrasie ${ }^{2}$ (HWA) en Hoof van Logistiekediens onderskeidelik. Die HWA, Hoof van Logistiekediens en GG was in hierdie stadium drie spesialisafdelings wat die KG in sy oorhoofse bevel- en beheerfunksie moes bystaan

Die verdediging van militêre funksies en verantwoordelikhede tussen die KG en die Sekretaris van Verdediging het sedert die ontstaan van die UVM probleme veroorsaak en onnodige oorvleueling tot gevolg gehad. In 1966 is die Versterkomitee aangestel om in te gaan op die verdeling van funksies binne die Departement van Verdediging en spesifiek ten opsigte van die funksies van die Sekretariaat van Verdediging.

$\mathrm{Na}$ aanleiding van hierdie komitee se bevindings is die pos van Sekretaris van Verdediging met ingang van 17 Oktober 1966 afgeskaf. Die funksies van die Sekretariaat moes noodwendig deur militêre stafafdelings geïnkorporeer word. Vir hierdie doel was dit onder andere nodig om ' $n$ afsonderlike finansiële beheerliggaam daar te stel om die rekenpligtige verantwoordelikheid van die Departement van Verdediging namens die KG te aanvaar. Dit het gelei tot die instelling van ' $n$ vierde spesialisafdeling onder die Komptroleur.

\section{Die Hoof van Weermagsadministrasie word Hoof van Personeel}

Verdere deurtastende ondersoek is ingestel om die integrasie van die destydse Sekretariaat finaal deur te voer. Die herorganisasie en herrangskikking is op 1 November 1968 finaal deurgevoer; met onder andere belangrike implikasies vir die Afdeling Personeel. Die Hoof van die Verdedigingstaf se organisasie is in twee eiesoortige afdelings verdeel, elk onder 'n Adjunkhoof van Verdedigingstaf met Administrasie (oorhoofse weermagsadministrasie) en Beplanning en Operasies respektiewelik as funksies. Verskeie administratiewe funksies van die Sekre- tariaat is aan die Verdedigingstaf oorgedra, sowel as sekere administratiewe funksies wat tot op daardie stadium deur die HWA behartig is. Dit het meegebring dat die HWA slegs sy funksies ten opsigte van personeeladministrasie oorgehou het. Die personeeladministrasie ten opsigte van burgerlike personeel wat vroeër deur die Sekretariaat behartig is, is by die Afdeling Weermagsadministrasie ingedeel en die titel van die beheerpos is op 1 November 1968 verander na Hoof van Personeel. Die afdeling het daarna bekend gestaan as die Afdeling Personeeladministrasie. Gedurende 1968 is ' $n$ vyfde spesialisstafafdeling ingestel toe die afdeling Burgerlike Beskerming ingestel is.

Hierdie voltooide proses van integrasie het meegebring dat die Sekretariaat van Verdediging in sy geheel ontbind is en dat die KG tegelyk hoofmilitêre uitvoerende offisier, hoofrekenpligtige beampte en permanente hoof van die Departement van Verdediging geword het. Daardeur is die ideaal om die Departement van Verdediging as een geïntegreerde verdedigingsorganisasie onder 'n enkele hoof saam te snoer verwesenlik.

Van belang in hierdie proses van integrasie en herorganisasie was ook die suiwering van die funksies van die Afdeling Personeel ten opsigte van personeel- en verwante personeelfunksies. Hierdie proses sou gedurende die volgende paar jaar voortgesit word totdat die Afdeling Personeel uiteindelik ' $n$ stafafdeling sou word wat uitsluitlik verantwoordelik is vir personeelaangeleenthede van die SAW.

\section{Hoof van Personeel word Direkteur- generaal Personeel}

Die snelle uitbreiding van die SAW as gevolg van die groeiende dreigemente teen die RSA het dit genoodsaak dat daar in 1970 weer organisatoriese aanpassings binne die bevel- en beheerstruktuur van die SAW gemaak moes word. Intensiewe ondersoek het getoon dat hoëvlak departementele administratiewe beheer, waaronder byvoorbeeld hoëvlak personeeladministrasie 'n steeds belangriker inslag in die groeiende Weermag gekry het. Gevolglik is daar besluit om die bostruktuur van die Departement van Verdediging sodanig te verander dat die $K G$ net nege direkte beheerpunte binne sy Departement sou hê. Bepaalde werksaamhede, veral met betrekking tot hoëvlakpersoneelsake, algemene administrasie, doeltreffendheidstudies en KMG-aangeleenthede is gedelegeer aan die be- 
kleër van 'n nuutgestigte pos van Hoof van Weermagsadministrasie. ${ }^{3}$ Die HWA was 'n vierbenige beheerliggaam waarbinne ingesluit was die Direkteur-generaal Personeel, KMG, Direkteur-generaal Algemene Administrasie en die Direkteur-generaal Bestuursdienste. Hiervolgens was die afdelingshoofde van genoemde vier spesialisafdelings direk verantwoordelik aan die Hoof van Weermagsadministrasie en nie meer aan die $K G$ soos voorheen die geval was nie. Dit kan gesien word as ' $n$ tussenbeheerpos wat moes dien om die aantal direkte beheerpunte binne die Departement van die KG te verminder. Op 29 September $1970^{4}$ het die posbenaming Hoof van Personeel verander na $\mathrm{Di}$ rekteur-generaal Personeel.

\section{Direkteur-generaal Personeel word Hoof van Staf Personeel}

Indringende ondersoeke is gedurende die volgende paar jaar gedoen ten opsigte van die bevel- en beheerstruktuur van die SAW. Na aanleiding van hierdie ondersoeke is belangrike aanpassings en veranderinge gemaak wat ook die Afdeling Personeel direk geraak het. Die poste van Bevelvoerende-Generaal Gesamentlike Gevegsmagte en Bevelvoerder Maritieme Verdediging is afgeskaf en die betrokke uitvoerende verantwoordelikhede is gedelegeer aan die Hoofde van die Leër, Lugmag en Vloot. Daardeur is 'n tussenbevelsvlak uitgeskakel en is die gevegsdienste direk onder beheer van die HSAW gebring. Die Geneeskundige $-{ }^{5}$ en Kapelaansdienste asook KMG is as ondersteunigsdienste geplaas wat aan die HSAW verantwoordelik was, maar regstreekse verpligtinge gehad het teenoor die gevegsdienste om bystand te verleen wanneer verlang word.

Die stafstruktuur is georganiseer op die grondslag van die gebruiklike staffunksies (in daardie stadium) van personeel, inligting, operasies en logistiek en hierdie patroon is eenvormig dwarsdeur die SAW toegepas. Op die vlak van die Verdedigingshoofkwartier het dit meegebring dat die HWA in verskeie komponente verdeel is binne die raamwerk van die nuwe stafstruktuur en dat ' $n$ nuwe stafafdeling vir die bestuur van logistiek geskep is. Elke stafafdeling het 'n Hoof van Staf gekry wat regstreeks aan sy bevelvoerder verantwoordelik was - aan die HSAW in die geval van die Verdedigingstafafdelings en aan die Hoofde van die drie Weermagsdele in die geval van Leër-, Lugmag- en Vlootstaf. Dit het tot gevolg gehad dat die pos van HWA op 15
April 1974 afgeskaf is en die ampstitel DGP op dieselfde datum verander het na Hoof van Staf Personeel.

Ten spyte van verdere veranderinge wat aangebring is ten opsigte van die stafstruktuur, byvoorbeeld die daarstelling van ' $n$ vyfde stafafdeling, Hoof van Staf Bestuursdienste (wat later Hoof van Staf Finansies geword het), kan bogenoemde datum gesien word as die datum waarop Hoof van Staf Personeel in sy huidige indeling binne die stafstruktuur van die SAW tot stand gekom het.

Voortspruitend uit die herorganisasie van die SAW bevel- en beheerstruktuur is die organisasie van Hoof van Staf Personeel (HSP) na 1974 aansienlik gewysig en uitgebrei. So byvoorbeeld is HBM op 1 Januarie 1975 afgedeel vanaf HSP na die Komptroleur, SAW. Die onderafdeling van die Regteradvokaat-generaal (RAG) wat sedert April 1974 funksioneel verdeel was tussen die Direkteur-generaal Algemene Administrasie (DGAA) en HSP is op 1 April 1975 in geheel as die Direktoraat Militêre Regspleging by HSP ingeskakel. Sedert daardie datum is HSP verantwoordelik vir die professionele beheer van die SAW se regsgeledere en regsaangeleenthede, die bestuur en beheer van tugreg in die SAW en die administrasie van alle wetgewing en die voortvloeiende delegasies.

Verder is HSP ook aangewys as die Korpsbevelvoerder van die Korps van Professionele Offisiere vir lede waarvan hulle hoofkwartiere die administrerende instansie sal wees terwyl die beherende funksies aan die onderskeie gebruikers toegesê is.

Die Hoof van staf Personeel oefen ook funksionele beheer uit oor die volgende eenhede van die SAW: Die Militêre Akademie, die Suid-Afrikaanse Verdedigingskollege, die Kollege vir Opvoedkundige Tegnologie en die personeel van sy onderskeie indiensnemingsentrums van die Direktoraat Mannekragvoorsiening op afgedeelde grondslag.

Op 1 April 1976 is drie nuwe direktorate tot HSP toegevoeg, te wete Direktoraat Algemene Personeeladministrasie (DAPA), Direktoraat Nasionale Dienspligadministrasie (DNDA), en die Direktoraat Burgerlike Personeeladministrasie (DBA). Die huidige samestelling van die afdeling van die Hoof van Staf Personeel sien as volg daaruit: Hoof van Staf Personeel is It-genl R.F. Holtzhauzen. Daar is drie Hoofdirekteure wat verantwoor- 
delik is vir Bemanning, Mannekraginstandhouding en Mannekragontwikkeling, terwyl die Direkteure Stafdienste, Militere Reg en Bestuursdiens ook direk aan HSP verantwoordelik is. Vyftien Direktorate word beheer deur die Hoofdirekteure en baie effektiewe beheer word op hierdie wyse uitgeoefen oor die Afdeling Personeel van die SAW.

Die personeelfunksie is sedert 1915 erken as afsonderlike Staffunksie binne die Suid-Afrikaanse Verdedigingsmag en is deur die jare gesuiwer van nie-personeelfunksies waarvoor die afdeling aanvanklik ook verantwoordelik was. Huidiglik is die afdeling van Hoof van Staf Personeel een van vyf stafafdelings van die Hoof van die SAW. In die lig van die totale aanslag teen Suid-Afrika is die doeltreffende uitvoering van die personeelfunksie dringend noodsaaklik. Daar kan met vrymoedigheid gekonstateer word dat die wyse waarop hierdie funksie binne die SAW deur die afdeling van Hoof van Staf Personeel beheer en bedryf word, doeltreffend voldoen aan die vereistes wat gestel word.

\section{Hoofde van die Afdeling Personeel sedert 1912}

\section{Adjudant-generaal}

1. Lt-kol J.J. Collyer (Hoofstafoffisier Generale Staf en Adjudant-generaal)

2. T/kol W.E.C. Tanner (Hoof van die Generale Staf en Adjudant-generaal)

3. Lt-kol H.S. Wakefield

2 Augustus 1915

14 Oktober 1919

1 November 1919 22 Junie 1933

17 Oktober 1933

2 Julie 1939

4. T/Kol B.J. Armstrong

5. Kol F.H. Theron

6. Brig L. Beyers (1942 bevorder tot genl-maj)

7. T/Genl-maj H.S. Wakefield

3 Julie 1939

8 April 1940

8 April 1940

4 November 1940

3 November 1940

31 Julie 1945

1 Augustus 1945

30 April 1946

8. Brig W.H. Hingeston
9. Brig S.J. Joubert

1 Februarie 1950 11 Januarie 1953

10. T/Brig P.H. Grobbelaar

12 Januarie 1953 30 April 1953

11. Kol R.C. Hiemstra

1 Mei 1953

14 Januarie 1959

12. Genl maj C.H.

1 Januarie 1960

Hartzenberg

\section{Hoof van Weermagsadministrasie}

13. Genl-maj C.H. Hartzenberg

1 Desember 1965

14. Genl-maj C.H.F. 14 Julie 1968 Markgraaf

13 November 1968

29 September 1970*

\section{Direkteur-generaal Personeel}

15. Genl-maj C.H.F. Markgraaf

29 September 1970* 15 April 1974

\section{Hoof van Staf Personeel}

16. Genl-maj C.H.F. Markgraaf

17. Lt-genl P.A. le Grange

18. V-Adm R.A. Edwards

19. Lt-genl G.J.J. Boshoff

20. Lt-genl R. F. Holtzhausen

1 Februarie 1981

* Sien voetnota $\mathrm{nr} 4$. * Kapt $R$ van Moltke, BA SOD is verbonde aan die Militêre Informasieburo
van die SAW.

\section{Voetnotas}

1. Hierdie opgradering was net tydelik. Brig L. Beyers is in 1942 bevorder tot genl-maj en sy opvolger, genl-maj H.S. Wakefield het dieseltde rang gehad, maar sy opvolger was weer eens 'n brigadier in die persoon van brig W.H. Hingeston. Op 1 Desember 1965 is die pos weer opgegradeer na dié van generaal-majoor.

2. Die ampstitel AG is reeds op 1 November 1965 verander na HWA (sien Witskrif 1960 tot 1970, 1 Januarie 1966, p 5).

3. Dit is belangrik om daarop te let dat die pos van HWA wat op 1 November 1965 ingestel is 'n naamsverandering was sonder dat die funksies verbonde aan die pos verander het. Die vervanging daarvan deur HP dui 
daarop dat HWA slegs die ampstitel van die afdeling personeel was. Die HWA pos van 1970 was 'n oorkoepelende beheerpos waaronder ook die afdeling personeel geval het.

4. Die presiese datum is moeilik bepaalbaar. Volgens lêer DGP/527/21, Inlae 71 dd 25 Februarie 1971 word die datum aangegee soos in the teks vermeld. Skeidingsblaaie is egter reeds op 24 Julie 1970 in lêers geplaas om HP en DGP korrespondensie te skei.

5. Korrespondensie op DGP-lêers is aangetref waarop die afdelingshoof reeds op 4 Julie 1970 as DGP geteken het, terwyl hy op 26 Junie nog as HP geteken het. 


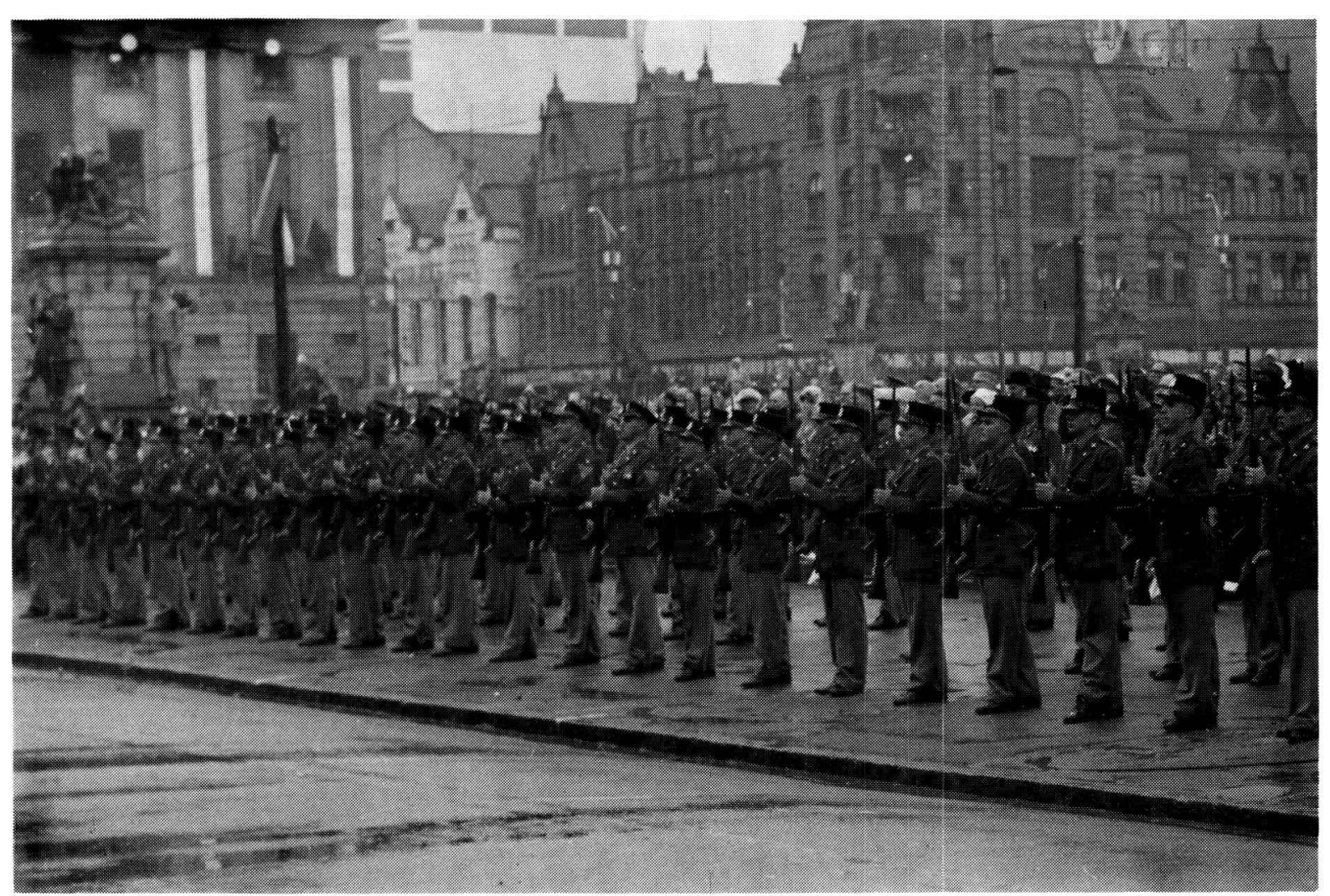

Republiekdag 31 Mei 1961 te Pretoria Inhuldiging van die eerste Staatspresident
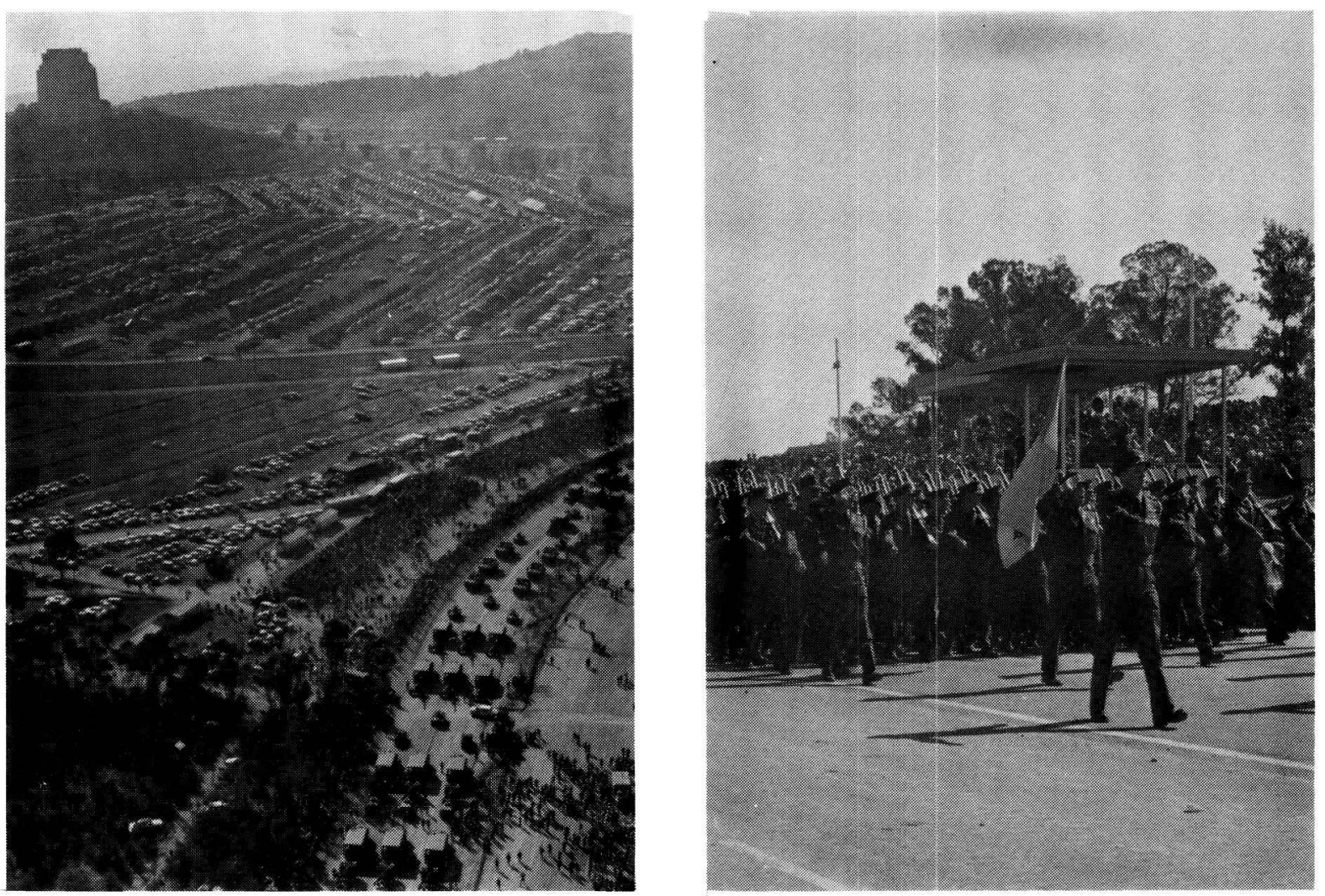

Die SA Weermag tydens die Republiekfees 1966 
Militêre Verbymars, strate van Durban, Republiekfees 1981
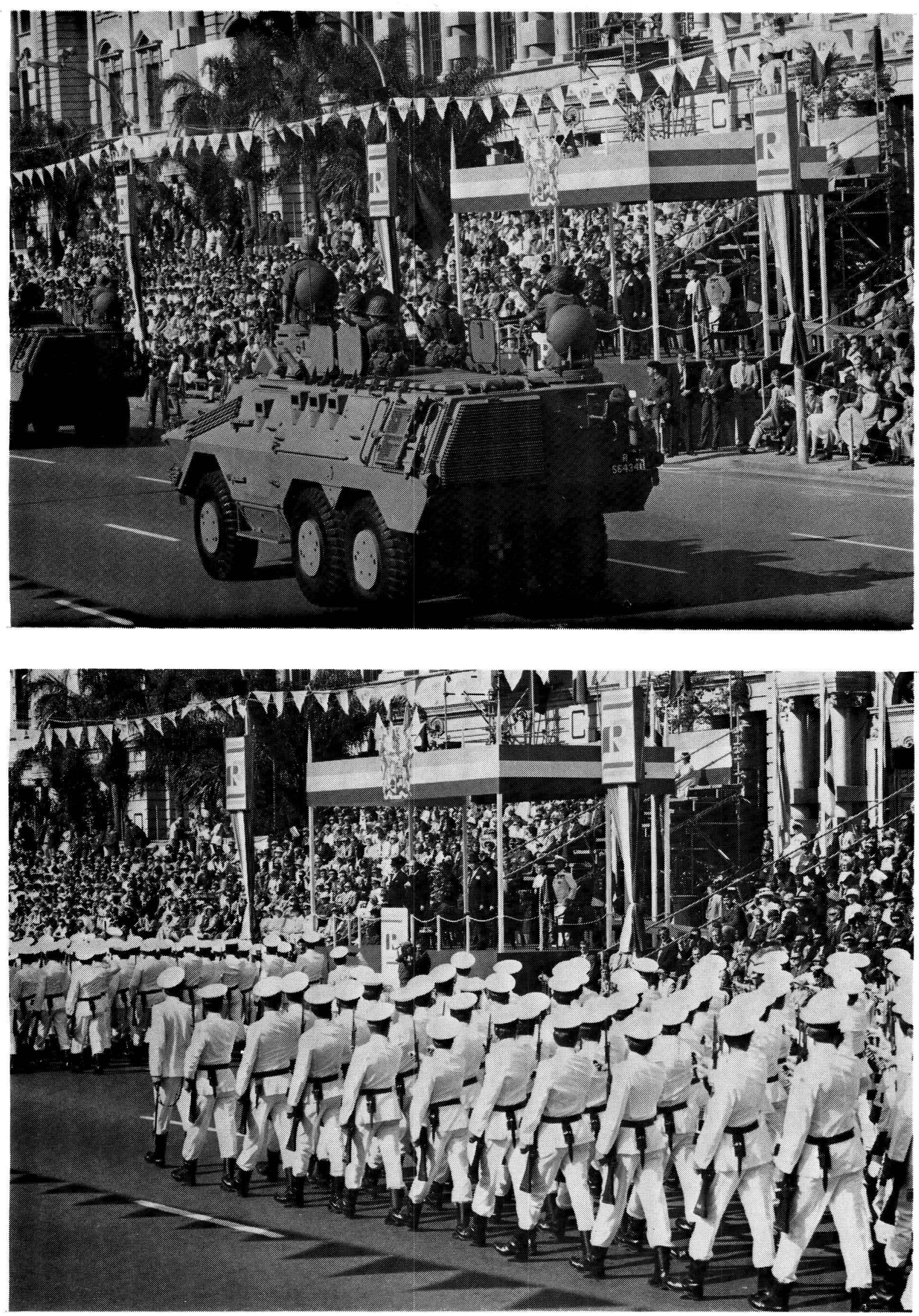


\section{Republiekfees 1981 te Durban: SAW deelname}
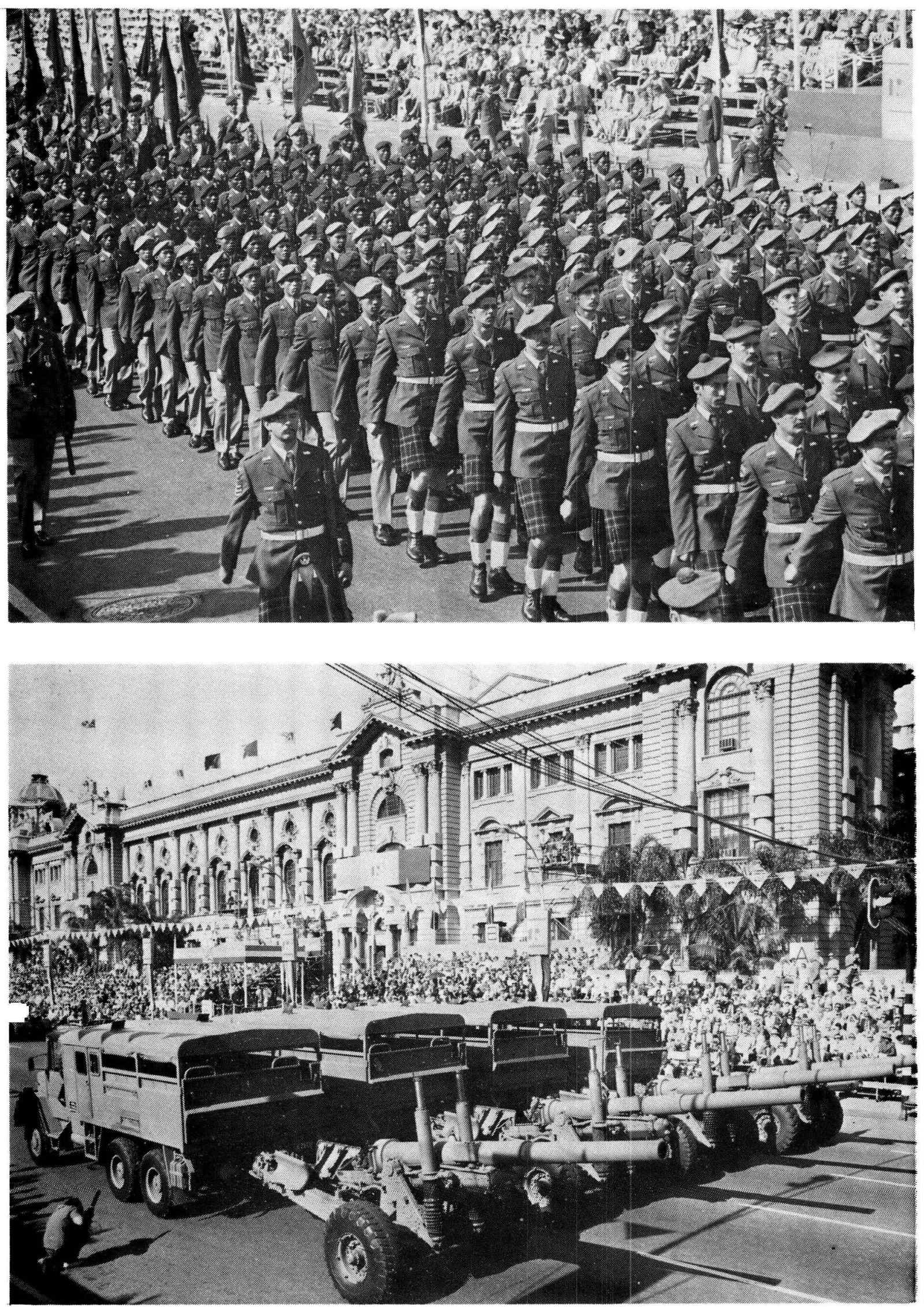


\section{SAW Deelname aan die Republiekfeesvieringe te Durban 1981}
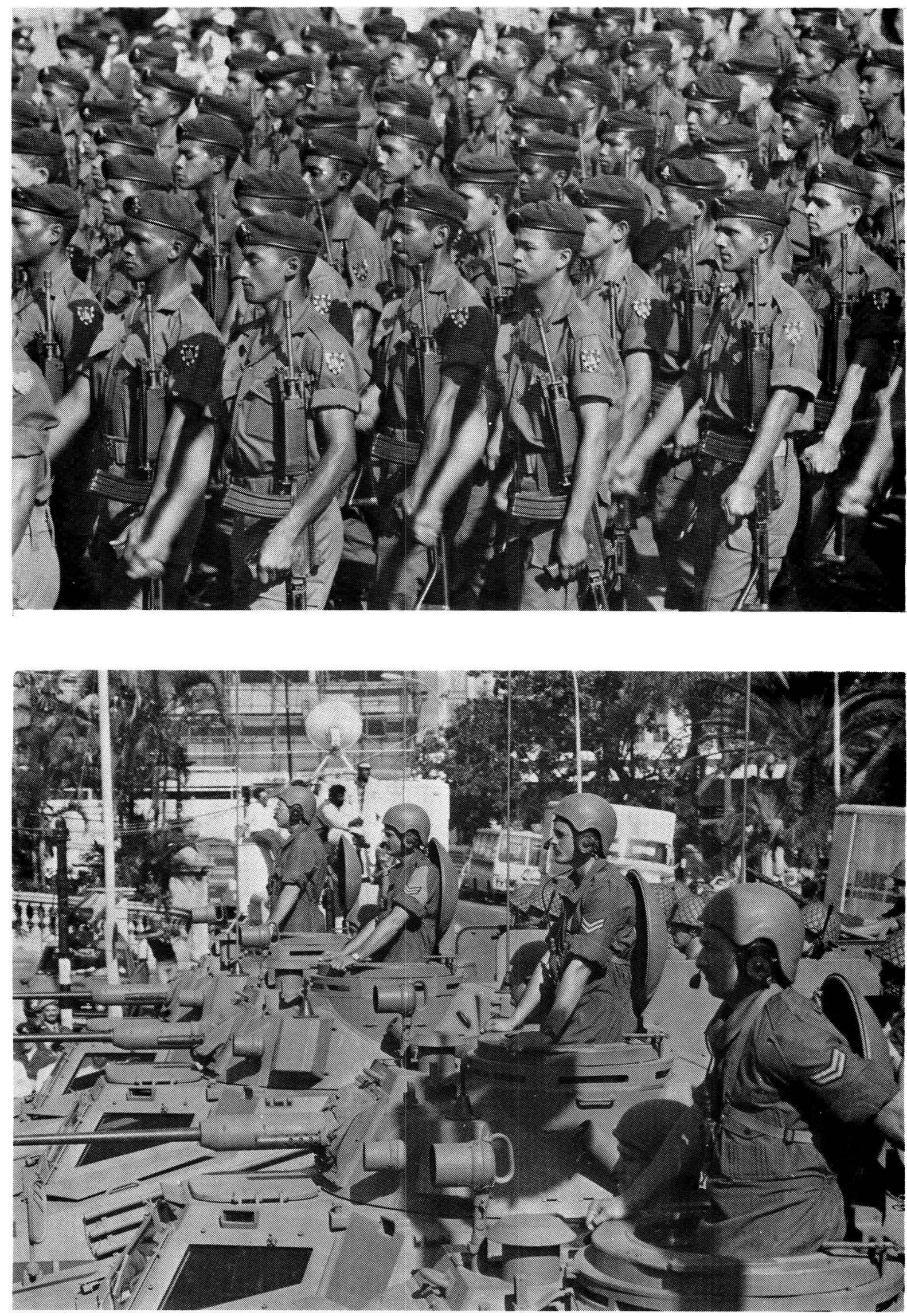